\title{
Healthcare on the water
}

\section{Lady-Jacqueline Aster lives on a 72 foot canal boat and is part of the boating community in the west of England. In this article, based on an interview recorded on her boat, she describes how she has worked hard to get good palliative care while maintaining her way of life}

A boat doesn't count as a permanent address, so it can be hard for boaters to register with a doctor. Officially in the UK you can register with a surgery and use its address for any correspondence - as long as you can get past the receptionists, who often don't know this. We get a lot of prejudice about our way of life, that we're all dirty and don't work. But it's such a diverse community; we've got so many people doing different jobs. We do work, and our children go to school. The boating community is a very close and caring one.

When I became ill, I kept going back to my doctor with a range of symptoms, and I was convinced there was one cause, but I didn't feel she took me seriously. I said to her, "I think I've got cancer, I can smell it," and she laughed at me. But my grandmother died of cancer, I thought: "I smell like what my nan smelt like"-almost like pork, like bacon that was on the turn.

I chose another doctor, who didn't know what was wrong but could see I was very ill and admitted me to hospital immediately. I had got adrenocortical cancer. It's very rare. I did my research, so I knew it would come back even after the surgery I had, and I insisted on seeing an oncologist. I've actually lost count of the number of times the cancer has come back.

My oncologist kept talking about clinical trials and drugs with a small percentage success rate. She actually said to me "I'm struggling to get my head around the fact that you don't want any more treatment." She shouldn't have shared that: what she's struggling to get her head around is nothing to do with me. But I do really feel for her, because she wants to make things better, she wants to cure me, and she can't. I don't want clinical trials,
I don't want experimental drugs, I want to be at home, feeling as well as I can.

I've got to the point now where I need carers, and they are all boaters. I employ them myself using the budget provided by my social worker. They know how things work on a boat. It's a completely different way of living to being in a house; you have to be careful not to use too much water or power. And emptying the chemical toilets ... I can't see an agency carer going 150 yards down the towpath with my bicycle and trailer and a plastic bucket of poo. There are jobs where you need to know what you are doing, like cleaning all the ash out of the stove and filling the coal scuttle up; carers have to be prepared to lift a bag of coal, and not mind if their hands get a bit dirty.

I have asked for regular scans so I can be prepared, and at some point I'm going to look at a scan and know I haven't got long. I've got it all sorted, and I've had some laughs planning my funeral with family and friends. I will be supported to die at home, and then I want to do things the old fashioned way: I want my body to be kept on the boat for a few days. I will go down the canal on my friends' beautiful wooden launch to trumpets played by musicians from the community and a procession down the towpath. I have friends who are performance artists and who have a hearse covered with skeletons and green lights, and that will take me from the canal to the burial ground. I can have it exactly how I want it.

Competing interests: I have read and understood BMJ policy on declaration of interests and declare the following: none.

Published by the BMJ Publishing Group Limited. For permission to use (where not already granted under a licence) please go to http://group.bmj.com/group/rights-licensing/ permissions 


\section{What you need to know}

- Make sure that you and your reception staff are aware of the rules about accepting patients who do not have a permanent address

- If your patient wants to talk about dying, talk about it; don't keep trying to fix things

- It is possible to adapt care to non-traditional settings; listen to your patients' suggested solutions 